\title{
“MAKE THE SUPERHERO GREAT AGAIN!": INTRODUCTION TO THE ISSUE
}

\section{Rastyam T. Aliev (a), Kwasu Tembo (b)}

(a) Astrakhan State University. Astrakhan, Russia. Email: rastaliev[at]gmail.com

(b) Independent researcher. Harare, Zimbabwe. Email: tembo.kwasu[at]gmail.com

\section{Abstract}

The article is an opening message from the journal's editors summarizing the key aspects of the issue.

Keywords

Superhero; Comics; Batman; Superman; Heroic; Mass Culture; Pop Culture; Cinema

This work is licensed under a Creative Commons «Attribution» 4.0 International License. 


\section{«СДЕЛАЕМ СУПЕРГЕРОЕВ СНОВА ВЕЛИКИМИ!»: ВВЕДЕНИЕ В НОМЕР}

\section{Алиев Растям Туктарович (a), Тембо Квасу (b)}

(а) ФГБОУ ВО "Астраханский государственный университет". Астрахань, Россия. Email: rastaliev[at]gmail.com

(b) Независимый исследователь. Хараре, Зимбабве. Email: tembo.kwasu[at]gmail.com

\section{Аннотация}

Статья представляет собой вступительное слово выпускающих редакторов, суммирующее ключевые аспекты выпуска.

\section{Ключевые слова}

Супергерой; Комикс; Бэтмен; Супермен; Героическое; Массовая культура; Попкультура; Кинематограф 


\section{INTRODUCTION}

The issues and debates concerning the concept of the heroic are an integral part of both ancient and modern cultures. The hero takes an important place in the formation of the cultural landscape. Oftentimes being a reflection of social ideals, and the psycho-spiritual precepts of a particular culture or society, the heroic not only reflects the social and economic norms of this or that epoch, but also at a certain moment begins to form them. That is why the theme of the heroic - with all its various ancillaries and permutations - becomes central to many mythological narratives, starting from antiquity all the way to our spectacular visual and pop cultural mythologies in late capitalism.

In recent pre-modern epochs, the theme of the heroic remained central for epic and historical discourses, and in the twentieth century it becomes one of the main ideological symbols of the Soviet state, for example. Over time, therefore, the image of a superhero has become one of the fundamental images in the mass culture of the 20th and 21st centuries. Coming down from the pages of American comics, they have made their way into the most diverse areas of modern culture: cinema, computer games, anime, cosplay, etc. They are no longer heroes only for young people, becoming a kind of cultural core around which a whole universe of images, ideas, meanings, concepts, etc. is built and orbits.

The emergence of the superhero phenomenon is connected with the neo-mythological paradigm of American Mass Culture as an integral feature of the early 20th century Modernist cultural model. The mass cultural emergence of the superhero appears in step with periods of global sociopolitical, economic, and cultural ennui. As a counter to the experiences of national depression, their emergence is inextricable from the collective dream of common Americans seeking support and encouragement during economic and social crises, united by the common name of the Great Depression. Despite their oftentimes alien provenance and superhuman powers and abilities, the new heroes of modern mass culture display such traits as an indomitable willingness to come to the aid of the everyman, to risk his own life, and the quintessence of heroism itself - death for the interests and well-being of others, particularly the innocent and the downtrodden.

It is certain that a superhero is a kind of litmus test that indicates or indexes the directions of modern society's development. But it is also a testing ground, where certain ideas are brought together in a state of flux and play, precipitating society's ability and interest in evaluatin its atti- 
tude toward each new image of a superhero, approaching it quite critically, accepting or rejecting it. Therefore, we can say that a superhero is a dynamic figure, developing as well as indicating the state of public moods, aspirations and expectations.

Actualization of the superhero character in the 21st century is a marker of complex global problems that humankind has faced. The study of this phenomenon in modern culture provides an opportunity to consider these problems from a new angle.

Researchers have approached the study of the phenomenon of the hero and heroic from a multitude of perspectives. First of all, we should mention the study of T. Carlyle's On Heroes, Hero-worship and the Heroic in History (1840), which examines the role of the individual in history. Undoubtedly, the central problem of the study is the "cult of the heroic" and the formation of the hero in his, her, or their historical retrospective.

The comic book and both the specifics of its narrative and aesthetic language are analyzed by the seminal work of J. Witek (1989), S. McCloud (1994), R. Harvey (1996), P. Lefevre (2000), Ch. Hatfield (2005), T. Groensteen (2009) and others. A collection of articles by M. T. Inge Comics as culture (1990) is devoted to the analysis of the place of comics among other art forms, as well as to its specificity in a highly syncretistic art. A noteworthy specialist in the history of early comics and protocols is D. Kunzle (2010). Likewise, the approach to superheroes of Sh. Rhoades (2008) can also be called historical.

B. Beaty (2007), J. Benson (2007), A. Spiegelman (2013), H. Chute (2013) focus on the problem of evidence and documentation capabilities of a comic book, while B. Wright implements a comprehensive approach to the history of a superhero as a spokesperson for certain ideas of national American consciousness (2003). Comprehensive analysis by P. Coogan's study is devoted to the genre specifics of superhero comics (2006). The problem of ideological content of superhero comics is raised in M. DiPaolo's War, Politics and Superheroes: Ethics and Propaganda in Comics and Film (2011), as well as in a collective monograph edited by C. York \& R. York, Comic Books and the Cold War, 1946-1962: Essays on Graphic Treatment of Communism, the Code and Social Concerns (2012).

Among modern researches of comics and images of superheroes, a collective work published under the title Superhero Bodies: Identity, Materiality, Transformation (Haslem, MacFarlane, \& Richardson, 2019) is worth mentioning. This book raises various questions concerning the body and physicality of superheroes. For example, the problems of identity through the prism of a superhero's physicality are discussed in the works of V. Tedeschi (2019), V. Trott (2019), W. Aateshah (2019) published in the book. 
M. Kobre, in his study entitled Only Transform The Monstrous Bodies of Superheroes analyzes the body of a superhero from the perspective of monster physicality (2019). E. Kendal in his essay When Superman Was Grown in a Tank (2019) reflects on the corporality of the famous Superman and his various iterations.

Another significant work in this area is C. Jeffery's book entitled The Posthuman Body in Superhero Comics: Human, Superhuman, Transhuman, Post/Human (2016). The author analyses the problems of body reflexion and physicality in superhero comics as issues of transhumanism and posthumanity. The evolution of the representation of the Batman and Superman bodies on the pages of comics is traced by a group of researchers from Brazil. They concluded that initially Batman and Superman were drawn with less muscular features, and the shape contemporary readers are used to began to appear much later (Correa, Capraro, \& Silva, 2019, p. 14).

Issues of female identity in the context of superheroic bodily integrity are analyzed in a work of $\mathrm{H}$. Pennell \& E. Behm-Morawitz. In their study, the researchers attempted to examine "the short-term effects of sexualized female characters in superhero movies
on female audience perceptions of gender roles, self-esteem and self-lense-
ness" $(2015$, p. 211).

The study found that

\begin{abstract}
"familiarity with images of sexualized female victims in superhero movies has reduced egalitarian views of gender roles. Exposure to images of a sexualized heroine resulted in a decrease in respect for the body. But the positive effect was manifested in greater confidence in the importance of body skills for the self-esteem of women who became acquainted with superhero characters" (2015, p. 219).
\end{abstract}

The evolution of female characters in the context of third wave feminism is traced in V. Curtis and V. Cardo. In this work, researchers analyze the important role of intersectionality, along with topics related to the body and sexuality, violence, solidarity and equality in comic books (2018, p. 381). Despite the importance of this issue, we can note a certain lack of research on comics as a cultural phenomenon in Russian scholarship. Special mention should be made of the contribution of D. Dmitrieva, who examines the genesis of the comic book and the phenomenon of a superhero in the context of visual culture of the $20^{\text {th }}$ century (2014). 


\section{MAKE THE SUPERHERO GREAT AGAIN!}

This issue was conceived quite a long time ago, but we started its implementation only in 2019, when we opened our own research journal Galactica Media, which was able to attract a huge audience and authors interested in researching the image of the superhero and comic books more generally. At a cursory glance, the title of this project may seem quite provocative at first sight. "Make the Superhero Great Again!" is a paraphrase of the election slogan of D. Trump (President of the United States), which is very similar to the phrase used by Bane (Tom Hardy) in C. Nolan's trilogy-concluding blockbuster The Dark Knight Rises, where he says: "Make Gotham Great Again!"(2012). The title of this issue does not nor is intended to carry any political context, but in light of current political and cultural issues, we also felt as if we could not ignore the very complex relationship between the symbolism, history, politics, counter-culture, and status-quo inherent in the issues and debates concerning the concept of the comic book superhero.

When we launched the project, we noticed that the geography of interested authors was growing daily. In particular, this project involves a large group of authors from different countries (Russia, Zimbabwe, USA, Brazil, China, Germany, Kyrgyzstan, Spain, Argentina and others). This indicates, first of all, the fact that the image of a superhero is relevant not only within the remit of American mass culture. It has long been a global cultural phenomenon that affects the development of local socio-cultural spaces.

We have ordered the incoming materials in five different sections of the issue. The first section, entitled Representing Superhero, includes articles by authors who in their research have dealt with various issues and debates concerning superhero image construction and their representation in philosophy and contemporary culture. For example, the first article Super-non-Hero: from Superpower to Ultra-Violence by Konstantin A. Ocheretyany examines the problem of changing the paradigm of a superhero in comic books. The author notes that since its inception, the superhero was the embodiment of the principles examined by Nietzsche and Freud in nature and culture: the superhuman and Super-Ego, which, according to Ocheretyany, redounds to the fact that latent to the concept of superpower is an obscene sadistic interiority. Ultimately, by analyzing the image of the superhero from a philosophical perspective, the author concludes that "a superhero begins to prescribe a moral model of nature and confront culture, and "sadism" of his actions (ie, destructive conse- 
quences) - a way to present a categorical imperative at the level of visual and imaginative language".

Arina A. Kutovaia and Ekaterina V. Mikhailovskaya in their article entitled The Myth of Batman: Intra- and Interdiscursive Transformations focus on the problem of representing the Batman image "as a collection of texts and a single process of their creation in different media, such as comics, animation, film and video games". Taynah Ibanez Barbosa \& Mateus Yuri Passos (Stepping out of Divinity: Tom King's "All-too-human" Batman) has the aim of understanding how subtle changes in the characterization of a superhero may make them more congruent with the current day morality and ideals of global, digital society, even if a given character is willing to directly challenge that morality. In Kwasu Tembo's essay entitled Why Superman Will Not Save the World: Theorizing the Relationship Between Suffering and DC Comics Superman, the author, equipped with psychoanalytical tools, demonstrates an inextricable link between comic book superheroes and suffering.

The section Superhero in Cinema opens with an article entitled "The Dark is Afraid of Me": Philosophical and Anthropological Issues in the Riddick Trilogy, in which Sergey A. Pesyakov shows the development of superhero storylines as monomythological constructs.

The authors from the section Literature and Superheroes, in which two articles have been published, address the question of heroic and superheroic constructions, which are the basis for the characters of classical and non-classical literary works. In them, the authors consider the images of protosuperheroes in Russian classical literature (Elena E. Zavyalova Protosuperheroes in Russian Classics of the $19^{\text {th }}$ century) and the problems of the heroic in the epic "Song about the Nibelungen" (Asia A. Sarakaeva \& Elina A. Sarakaeva Hero and Fate in the Nibelungenlied).

The section Superhero: from Theory to Sociocultural Practice is dedicated to the problems of research into the construction of socio-cultural reality in the context of the superhero. There are two articles in this section: Maksym W. Kyrchanoff's Invent, Deconstruct and Reinvent the Superhero: the Misadventures of the National Hero in the Modern Cultures of Nationalism (from the Nationalist Political Poster to the Comic Book of Mass Culture) and Natalia V. Kuzina's The Role of the Superhero in the Formation of the Russian Sociocultural Space.

We decided to title the last section Global \& Local Superhero. Here, we have combined authors' articles that address the problems of global and local cultures and their impact on the global socio-cultural space. For example, this section opens with Anja Lange's The Beginning of Ukrman - a Fighter against the Evil and the Coronavirus, in which the au- 
thor introduces the Ukrainian superhero Ukrmen. In the article, the author explores the issues of reflection in this superhero of those socio-cultural processes and phenomena that are typical of contemporary Ukraine. Samantha da Silva Diefenthaeler's article Notes on Penthesilea: the Marks of a Past of Female Heroism explores the problem of representation of female superheroic images in modern culture. Lastly, Vinodh Venkatesh in his essay entitled Argentina in Crisis: Superheroes in Zenitram (2010) and Kryptonita (2015) describes Latin American superheroic images relevant to Argentina and how these images are represented on television.

We very much hope that this issue will be interesting not only for researchers of mass and comic book culture, but also for all interested in the research problems addressed by our contributors.

\section{ACKNOWLEDGEMENTS}

We would like to thank all the authors who took part in this project, and the entire editorial team of Galactica Media, who helped with the production of the issue and its publication.

\section{References}

Aateshah, W. (2019). Empowered and Strong Muslim Female Community in Ms. Marvel. In W. Haslem, E. MacFarlane, \& S. Richardson (Eds.), Superhero Bodies: Identity, Materiality, Transformation (pp. 59-73). Oxford: Routledge.

Beaty, B. (2007). Unpopular Culture: Transforming the European Comic Book in the 1990s. University of Toronto Press.

Benson, J. (2007). Confessions, Romances, Secrets and Temptations: Archer St. Fohn and the St. Fohn Romance Comics. Fantagraphics.

Carlyle, T. (1840). On Heroes, Hero-worship and the Heroic in History. London: Chapman and Hall.

Chute, H. L. (2013). Graphic Women: Life Narrative and Contemporary Comics. Columbia University Press.

Coogan, P. (2006). Superhero: the secret origin of a genre. MonkeyBrain Books.

Correa, C., Capraro, A. M., \& Silva, M. E. (2019). The Body Patterns in Batman and Superman HQS (1938-2016). Materiales para la Historia del Deporte(19), 14-26. (in Portuguese).

Curtis, N., \& Cardo, V. (2018). Superheroes and third-wave feminism. Feminist Media Studies, 18(3), 381-396. Doi: 10.1080/14680 777.2017.1351387.

DiPaolo, M. (2011). War, Politics and Superheroes: Ethics and Propaganda in Comics and Film. McFarland. 
Dmitrieva, D. G. (2014). The Phenomenon of an American Superhero in the Context of Visual Culture of the 20th century. PhD thesis. Moscow. (In Russian)

Groensteen, T. (2009). The System of Comics. University Press of Mississippi.

Harvey, R. C. (1996). The Art of the Comic Book: An Aesthetic History (Studies in Popular Culture). University Press of Mississippi.

Haslem, M., MacFarlane, E., \& Richardson, S. (Eds.). (2019). Superhero Bodies: Identity, Materiality, Transformation. Oxford: Routledge.

Hatfield, C. (2005). Alternative Comics: An Emerging Literature. University Press of Mississippi.

Inge, M. T. (1990). Comics as culture. University Press of Mississippi.

Jeffery, S. (2016). The Posthuman Body in Superhero Comics: Human, Superhuman, Transhuman, Post/Human. Palgrave Macmillan US.

Kendal, E. (2019). When Superman Was Grown in a Tank. In W. Haslem, E. MacFarlane, \& S. Richardson (Eds.), Superhero Bodies: Identity, Materiality, Transformation (pp. 133-148). Oxford: Routledge.

Kobre, M. (2019). Only Transform The Monstrous Bodies of Superheroes. In W. Haslem, E. MacFarlane, \& S. Richardson (Eds.), Superhero Bodies: Identity, Materiality, Transformation (pp. 149-160). Oxford: Routledge.

Kunzle, D. (2010). Father of the Comic Strip: Rodolphe Topffer. Press of Mississippi.

Lefevre, P. (2000). Comics \& Culture: Analytical and Theoretical Approaches to Comics. Museum Tusculanum Press.

McCloud, S. (1994). Understanding Comics. Harper Collins.

Pennell, H., \& Behm-Morawitz, E. (2015). The Empowering (Super) Heroine? The Effects of Sexualized Female Characters in Superhero Films on Women. Sex Roles, 72(5-6), 211-220. Doi: 10.1007/s11 199-015-0455-3.

Rhoades, S. (2008). A Complete History of American Comic Books. Peter Lang.

Spiegelman, A. (2013). Co-Mix: A Retrospective of Comics, Graphics, and Scraps. Drawn $\&$ Quarterly Publications.

Tedeschi, V. (2019). Poison Ivy, Red in Tooth and Claw: Ecocentrism and Ecofeminism in the DC Universe. In W. Haslem, E. MacFarlane, \& S. Richardson (Eds.), Superhero Bodies: Identity, Materiality, Transformation (pp. 37-46). Oxford: Routledge.

Trott, V. (2019). "Let's start with a smile" Rape Culture in Marvel's Jessica Jones. In W. Haslem, E. MacFarlane, \& S. Richardson (Eds.), Superhero Bodies: Identity, Materiality, Transformation (pp. 47-58). Oxford: Routledge.

Witek, J. (1989). Comic Books as History: The Narrative Art of Jack Jackson, Art Spiegelman, and Harvey Pekar (Studies in Popular Culture). University Press of Mississippi. 
Wright, B. W. (2003). Comic Book Nation: The Transformation of Youth Culture in America. JHU Press.

York, C., \& York, R. (Eds.). (2012). Comic Books and the Cold War, 1946-1962: Essays on Graphic Treatment of Communism, the Code and Social Concerns. McFarland.

\section{Список литературы}

Aateshah, W. (2019). Empowered and Strong Muslim Female Community in Ms. Marvel. In W. Haslem, E. MacFarlane, \& S. Richardson (Eds.), Superhero Bodies: Identity, Materiality, Transformation (pp. 59-73). Oxford: Routledge.

Beaty, B. (2007). Unpopular Culture: Transforming the European Comic Book in the 1990s. University of Toronto Press.

Benson, J. (2007). Confessions, Romances, Secrets and Temptations: Archer St. Fohn and the St. Fohn Romance Comics. Fantagraphics.

Carlyle, T. (1840). On Heroes, Hero-worship and the Heroic in History. London: Chapman and Hall.

Chute, H. L. (2013). Graphic Women: Life Narrative and Contemporary Comics. Columbia University Press.

Coogan, P. (2006). Superhero: the secret origin of a genre. MonkeyBrain Books.

Correa, C., Capraro, A. M., \& Silva, M. E. (2019). The Body Patterns in Batman and Superman HQS (1938-2016). Materiales para la Historia del Deporte(19), 14-26. (in Portuguese).

Curtis, N., \& Cardo, V. (2018). Superheroes and third-wave feminism. Feminist Media Studies, 18(3), 381-396. Doi: 10.1080/14680 777.2017.1351387.

DiPaolo, M. (2011). War, Politics and Superheroes: Ethics and Propaganda in Comics and Film. McFarland.

Groensteen, T. (2009). The System of Comics. University Press of Mississippi.

Harvey, R. C. (1996). The Art of the Comic Book: An Aesthetic History (Studies in Popular Culture). University Press of Mississippi.

Haslem, M., MacFarlane, E., \& Richardson, S. (Eds.). (2019). Superhero Bodies: Identity, Materiality, Transformation. Oxford: Routledge.

Hatfield, C. (2005). Alternative Comics: An Emerging Literature. University Press of Mississippi.

Inge, M. T. (1990). Comics as culture. University Press of Mississippi.

Jeffery, S. (2016). The Posthuman Body in Superhero Comics: Human, Superhuman, Transhuman, Post/Human. Palgrave Macmillan US.

Kendal, E. (2019). When Superman Was Grown in a Tank. In W. Haslem, E. MacFarlane, \& S. Richardson (Eds.), Superhero Bodies: Identity, Materiality, Transformation (pp. 133-148). Oxford: Routledge. 
Kobre, M. (2019). Only Transform The Monstrous Bodies of Superheroes. In W. Haslem, E. MacFarlane, \& S. Richardson (Eds.), Superhero Bodies: Identity, Materiality, Transformation (pp. 149-160). Oxford: Routledge.

Kunzle, D. (2010). Father of the Comic Strip: Rodolphe Topffer. Press of Mississippi.

Lefevre, P. (2000). Comics \& Culture: Analytical and Theoretical Approaches to Comics. Museum Tusculanum Press.

McCloud, S. (1994). Understanding Comics. Harper Collins.

Pennell, H., \& Behm-Morawitz, E. (2015). The Empowering (Super) Heroine? The Effects of Sexualized Female Characters in Superhero Films on Women. Sex Roles, 72(5-6), 211-220. Doi: 10.1007/s11 199-015-0455-3.

Rhoades, S. (2008). A Complete History of American Comic Books. Peter Lang.

Spiegelman, A. (2013). Co-Mix: A Retrospective of Comics, Graphics, and Scraps. Drawn $\&$ Quarterly Publications.

Tedeschi, V. (2019). Poison Ivy, Red in Tooth and Claw: Ecocentrism and Ecofeminism in the DC Universe. In W. Haslem, E. MacFarlane, \& S. Richardson (Eds.), Superhero Bodies: Identity, Materiality, Transformation (pp. 37-46). Oxford: Routledge.

Trott, V. (2019). "Let's start with a smile" Rape Culture in Marvel's Jessica Jones. In W. Haslem, E. MacFarlane, \& S. Richardson (Eds.), Superhero Bodies: Identity, Materiality, Transformation (pp. 47-58). Oxford: Routledge.

Witek, J. (1989). Comic Books as History: The Narrative Art of Jack Jackson, Art Spiegelman, and Harvey Pekar (Studies in Popular Culture). University Press of Mississippi.

Wright, B. W. (2003). Comic Book Nation: The Transformation of Youth Culture in America. JHU Press.

York, C., \& York, R. (Eds.). (2012). Comic Books and the Cold War, 1946-1962: Essays on Graphic Treatment of Communism, the Code and Social Concerns. McFarland.

Дмитриева, Д. Г. (2014). Феномен американского супергероя в контексте визуальной культуры XX века. PhD thesis. Москва. 